\title{
COVID-19 Policies can Perpetuate Violence Against Transgender Communities: Insights from Peru
}

\author{
Amaya Perez-Brumer ${ }^{1}$. Alfonso Silva-Santisteban ${ }^{2}$
}

Published online: 27 April 2020

(c) Springer Science+Business Media, LLC, part of Springer Nature 2020

Globally the novel coronavirus that causes COVID-19 disease has laid bare the politics and social inequities that contribute to the elevated distribution of illness and mortality among socially marginalized communities. While rapid structural responses such as curfews, physical distancing protocols, and travel restrictions have greatly curtailed the spread of COVID-19 and effectively saved lives [1], we are also witnessing the alarming emergence of policies that enact and perpetuate violence against transgender communities. Panama, Peru, and Colombia (though only in Bogota) have legislated policies to enforce physical distancing by restricting the mobility of its citizens based on binary understandings of gender and associated norms [2,3]. Meaning that on alternating days women are allowed to access essential services and on the other days, men. What about people and communities that exist outside of hegemonic understandings of binary gender presentation and identities? As has become clear these policies are not solely logistically problematic for transgender communities to negotiate. The implementation and policing of these binary, gender-based laws have also resulted in direct violence perpetrated against transgender communities [4].

A closer assessment of the Peruvian case, quite unique in that a little over a week after implementation their genderbased policy was rescinded [5], illustrates how policies and the violence and suffering they fuel can also magnify HIV vulnerabilities impacting transgender communities. Further, the rise of transgender activism contesting these social policies alongside grassroots mobilization efforts underscore

Amaya Perez-Brumer

a.perezbrumer@utoronto.ca

1 Division of Social and Behavioural Sciences, Dalla Lana School of Public Health, University of Toronto, Toronto, Canada

2 Center for Interdisciplinary Research On Sexuality, AIDS and Society, Universidad Peruana Cayetano Heredia, Lima, Peru the critical role of civil society in promoting solidarity and social justice during the COVID-19 pandemic.

In efforts to contain COVID-19, the Peruvian Government enacted a policy to restrict the mobility of its citizens based on gender. As described by Peru's President Martín Vizcarra, on Monday, Wednesday and Friday only men can go out and on Tuesday, Thursday and Saturday only women. On Sunday no Peruvian citizens would be allowed to leave their homes [6]. These restrictions were widely disseminated via the Government-sponsored messaging including infographics and circulated on various social media platforms, online newspapers and television news stations, and via printed pamphlets posted in public spaces routinely patrolled to ensure physical distancing.

This policy represented an escalation and the country's most stringent legal measure to date in response to the urgent need to enforce physical distancing to keep the novel coronavirus from spreading faster than the Peruvian health system can respond. According to the Peruvian government, as of mid-April 2020 there were over 25,000 confirmed cases of the coronavirus and at least 700 people have died of complications related to COVID-19 [7]. Gender restrictions were implemented within the existing national emergency which included country-wide curfews limiting any travel after $6 \mathrm{pm}$, enforced by the Peruvian armed forces and police [8] Indeed, since implementation more than 50,000 people have been detained and then released for breaking these newly enacted laws [9].

Policing of these laws has been particularly brutal among the Peruvian transgender community as documented by videos, photos, and comments circulating on social media. For example, one video evidenced three transgender women being publicly humiliated by the police, made to squat and bounce while forced to declare "I want to be a man, I want to be a man" [10]. Further accounts demonstrate physical and symbolic violence targeting transgender women including physical assault, gender policing, and other transphobic actions $[11,12]$. 
In response, transgender activists protested the explicit transphobia underscoring the gender-based restrictive social policy. Namely, that this law reinforces the gender-binary and places transgender people in a grey zone of when they are legally allowed to access needed services such as food and medical supplies. Confusion over when trans people are allowed to access essential services further exposes them to violence through policing carried out by law enforcement and civil society more broadly. While surveillance of this law is based on physical appearance, citizens are required to show their national identity document if stopped by the police. Physical expressions of gender identity vary and access to gender affirming procedures and resources are deeply impacted by cost. Further, in the absence of a gender identity law, gender congruent identity documents require many arduous and expensive processes. Gender congruent IDs, thus, are inaccessible for the majority of Peruvian transgender women.

To address these controversies President Vizcarra stated that the government is "progressive" and that "the armed forces and national police will have clear instructions so that this is not at all a pretext for any homophobic measure" [13]. While President Vizcarra should be commended for trying to implement stigma-reduction protocols and publicly denounced discrimination that surged from this genderbased population control strategy, in practice, his statement was simply not enough. Within the first two days following the implementation of gender restrictions, the Observatory of LGBTQ Human Rights at the Universidad Peruana Cayetano Heredia documented eleven cases of violence and related suffering experienced by gender non-binary people directly related to this law. Ultimately, the enactment of this policy intervention has reified ID documents as both a structural determinant of health for transgender people and a fundamental human right.

This policy was a striking failure. As an over-simplistic method to control population mobility, it ignored the reality of Peru as a machista society and assumed gender equality in the functioning of everyday life. On days permitting mobility of women, grocery stores and other essential services where overcrowded and overrun [14], failing to achieve the aim of the social policy which was to promote physical distancing measures. For the transgender community the impact was not simply a failure, but rather incited transphobic violence and infringements on their basic human rights. The gender-based mobilization restriction policy was rescinded by decree from the Peruvian government [5].

After four decades of living with and responding to the HIV epidemic, we know that restrictive, and punitive social policies often disproportionately infringe upon the human rights of already vulnerable communities [15]. Peruvian transgender people traverse multiple marginalized statuses (e.g. transgender, sex worker, economically and socially disenfranchised, food insecure, migrant, minor, etc.) which intersect to constitute vulnerability to HIV [16, 17]. It stands to reason that these factors will also place transgender communities at greater vulnerability to COVID-19.

Any lockdown policy may yield disproportionate consequences and exacerbate health inequalities for marginalized communities, including but not limited to transgender people. The loss of livelihood and lack of food, shelter, health, and other basic necessities will disproportionately impact the most vulnerable of society, placing them at heightened vulnerability for HIV, COVID-19 and/or other adverse health outcomes. However, compulsory lockdown policies, to date, are our most effect tool against COVID-19. While we are in a crisis, thoughtful interrogation of potential deleterious impacts of such policies need to occur before implementation and be matched with social services for people most in need.

As we continue to navigate COVID-19 in the absence of state-led protections for transgender communities, activism and solidarity efforts cannot be ignored. Grassroots movements were a defining characteristic of the early response to the HIV epidemic, and similarly Peruvian transgender activism and grassroots mobilization has surged on virtual social media platforms, namely Facebook and WhatsApp. In part, these efforts solidified as resistance to compulsory blanket policies, yet, have morphed and extended far beyond. While more examples are emerging daily, meaningful responses by and for trans people include: proactive network mapping to disseminate COVID-19 related information, crowd-sourcing funds to secure food, pay rent and/or secure housing, and grocery shopping provided by trans people for trans people who for whatever reason are unable to seek and secure food $[12,18]$.

The Peruvian context exemplifies one of many blanket policies being enacted in response to COVID-19 that take for granted economic, housing, and food security that for many transgender women and also for millions of others represent basic human rights that are out of reach. Such measures place the burden of health on individual behavior, invisibilizing the structural forces that shape one's ability to stay isolated. It is of vital importance, therefore, to think critically about how the use of emergency powers translate into police brutality to enforce these measures and how existing societal inequalities pattern violence against certain groups of people.

What COVID-19 and the associated gender-based policy have magnified is the endemic and routine nature of violence and marginalization experienced by transgender communities, too often at the hands of police. Yet, as we saw with the history of the HIV and AIDS epidemic, through processes of normalization and bureaucratization denying these realities for socially oppressed groups are far too easy and have taken a serious toll on the effective global response. It is 
imperative to name and document violence and, importantly, respect and learn from rapidly evolving grassroots mobilization efforts to establish broader-scale interventions and policies that will equitably protect vulnerable communities as we jointly live through and emerge from the COVID-19 pandemic.

Acknowledgements Authors would like to express their deep gratitude for the information provided by Leyla Huerta and Gianna Garcia and acknowledge the tremendous solidarity of Peruvian transgender communities as they mobilize to address COVID-19.

\section{References}

1. Nussbaumer-Streit B, Mayr V, Dobrescu AI, Chapman A, Persad E, Klerings I, et al. Quarantine alone or in combination with other public health measures to control COVID-19: a rapid review Cochrane Infectious Diseases Group. Cochrane Database Syst Rev. 2020;4(2):013574.

2. Aquino M, Moreno E. Gender divide: Peru, Panama limit men and women to alternate days out to stall the virus. Reuters. https:// www.reuters.com/article/us-health-coronavirus-peru/gender-divid e-peru-panama-limit-men-and-women-to-alternate-days-out-tostall-virus-idUSKBN21K39N. Accessed 2, Apr 2020

3. Jaramillo A. Bogota is hers on even days, his on odd days during lockdown. Bloomberg. Available from: https://www.bloomberg. com/news/articles/2020-04-08/bogota-is-all-her-s-on-even-dayshis-on-odds-days-for-lockdown. Accessed 8, Apr 2020

4. Solis L, Bueno D. Estado de emergencia: ¿cómo afecta el nuevo 'pico y placa' de género a la comunidad trans? La República. https://larepublica.pe/genero/2020/04/02/coronavirus-peru-lgtbimplicancias-en-medidas-del-ultimo-discurso-de-martin-vizca rra-atmp/. Accessed 2, Apr 2020

5. Gobierno anula restricción por género: solo podrá salir una persona por núcleo familiar. La República. https://larepublica.pe/ sociedad/2020/04/10/gobierno-anula-restriccion-por-genero-solopodra-salir-una-persona-por-nucleo-familiar/ Accessed 10, Apr 2020

6. COVID-19 Decreto Supremo No 057-2020-PCM https://busqu edas.elperuano.pe/normaslegales/decreto-supremo-que-modif ica-el-articulo-3-del-decreto-supre-decreto-supremo-no-0572020-pcm-1865326-2/. Accessed 2, Apr 2020

7. Instituto Nacional de Salud y Centro Nacional de Epidemiología, Prevención y Control de Enfermedades. Sala Situacional COVID19 Perú [Internet]. Perú Ministerio de Salud. Available from: https ://covid19.minsa.gob.pe/sala_situacional.asp

8. Prórroga del Estado de Emergencia Nacional declarado mediante Decreto Supremo N $^{\circ}$ 044-2020-PCM-DECRETO SUPREMO-N ${ }^{\circ}$ 051-2020-PCM. Available from: https://busquedas.elperuano.pe/ normaslegales/prorroga-del-estado-de-emergencia-nacional-decla rado-mediant-decreto-supremo-no-051-2020-pcm-1865180-2/. Accessed 27, Mar 2020
9. Coronavirus en Perú: suman más de 52 mil los detenidos desde que inició el aislamiento social obligatorio. Gestión Perú. https:// gestion.pe/peru/coronavirus-peru-suman-mas-de-52-mil-los-deten idos-desde-que-inicio-el-aislamiento-social-obligatorio-estad o-de-emergencia-nndc-noticia/. Accessed 7, Apr 2020

10. Separan a policías que sometieron a castigos a mujeres transgénero en el Callao [VIDEO]. La República https://larepublica.pe/ sociedad/2020/04/07/callao-separan-a-policias-que-sometieron -a-castigos-fisicos-a-mujeres-trans-video/ Accessed 6, Apr 2020

11. Denuncian que policías exigieron pase peatonal y DNI a dos mujeres transgénero [VIDEO]. La República https://larepublic a.pe/sociedad/2020/04/04/coronavirus-en-peru-cercado-de-limadenuncian-que-policias-exigieron-pase-peatonal-y-dni-a-dosmujeres-transgenero-covid-19-pnp-transfobia-video/ Accessed 4, Apr 2020

12. Delcore AL. La lucha de las mujeres trans en tiempos de pandemia. El Comercio [Internet]. 2020 Apr 7. Available from: https ://especiales.elcomercio.pe/?q=especiales/mujeres-trans-en-tiemp os-de-pandemia-ecpm/index.html

13. Martín Vizcarra: Restricción de salida por días no es pretexto para ninguna medida de homofobia [VIDEO]. RPP Noticias https://rpp. pe/politica/gobierno/martin-vizcarra-restriccion-de-salida-pordias-no-es-pretexto-para-ninguna-medida-de-homofobia-video -noticia-1256046 Accessed 2, Apr 2020

14. Perú cancela la segregación de hombres y mujeres para transitar en cuarentena. EFE Noticias https://www.efe.com/efe/ameri $\mathrm{ca} /$ sociedad/peru-cancela-la-segregacion-de-hombres-y-mujer es-para-transitar-en-cuarentena/20000013-4218365 Accessed 10, Apr 2020

15. Mayer KH, Sohn A, Kippax S, Bras M. Addressing HIV criminalization: science confronts ignorance and bias. J Int AIDS Soc. 2018;21(7):e25163.

16. Silva-Santisteban A, Raymond HF, Salazar X, Villayzan J, Leon $\mathrm{S}, \mathrm{McF}$ arland W, et al. Understanding the HIV/AIDS Epidemic in Transgender Women of Lima. Peru: Results from a Sero-Epidemiologic Study Using Respondent Driven Sampling. AIDS Behav; 2011.

17. Perez-Brumer A, Silva-Santisteban A, Salazar X, Vilela J, Reisner SL. In search of "my true self": Transmasculine gender identity processes, stigma, and mental health in Peru. In: Nakamura N, Logie C, editors. Perspectives on sexual orientation and diversity LGBTQ mental health International perspectives and experiences. 2020. pp. 13-27.

18. Estado de emergencia: personas transgénero podrán denunciar actos de violencia. La República https://larepublica.pe/gener o/2020/04/03/estado-de-emergencia-en-peru-lanzan-web-paradenunciar-actos-transfobicos-atmp/?fbclid=IwAR0zRAU5gqBN8 bU6e6G4RXfUcn2GkysyIm_ECG0gx21of9szDMk4z727juM Accessed 3, Apr 2020

Publisher's Note Springer Nature remains neutral with regard to jurisdictional claims in published maps and institutional affiliations. 